\title{
Application of Phonovision Articulatory Method in Enrolled Students of Public Schools at South of Brazil in Young and Adult Education
}

\author{
Marines Boncoski Brizola \\ Education Department of the Porto Alegre City Hall, Porto, Brazil \\ Email: marinesbrizola@gmail.com
}

Received 31 March 2016; accepted 28 May 2016; published 31 May 2016

Copyright (C) 2016 by authors and Scientific Research Publishing Inc.

This work is licensed under the Creative Commons Attribution International License (CC BY). http://creativecommons.org/licenses/by/4.0/

\section{(c) (i) Open Access}

\begin{abstract}
The present article has the main objective introducing the Phonovision Articulatory Method as some possible actions to inclusion of enrolled students of schools with Young and Adult People Education modality. This research focused on with three persons: two being lightly mental deficient and another one with phonological deviation due delay of speaking. All the selected students have reported and are enrolled in public high schools at the South of Brazil. The research links to a study of case, considering that this testing has occurred in only one school with a reduced participation of these students. Through the obtained data with this study of case, it was possible to verify the increasing advances in reading and writing of persons exposed to phono articulatory method, even that this didactical resource has been developed to initial children schools in learning the Portuguese language.
\end{abstract}

\section{Keywords}

Phonovision Articulatory Method, Didactical, Young and Adult People Education Modality, Special Learning

\section{Introduction}

Even considering the high level of young and adult persons who get away from School Brazilian System, the country has made a specific modality in Basic Education throughout LDB Lei de Diretrizes e Bases da Educação Nacional de Jovens e Adultos (EJA) (Law of Directives and Bases of the National Youth and Adult Education). 
The introducing of this modality in basic education emerges the insertion of students who have special needs and they are accepted as regular students in public schools. These persons need some specific attentions, teaching materials and methodologies consistent with their learning necessities, According to surveys of 2012:

The census data shown that 105.205 students with special needs are enrolled in EJA, at Brazil in 2012. And, specifically, $46.69 \%$ were in regular schools and $52.31 \%$ at the special learning (Meleti, 2014).

Based on the presented data, it has reinforced the importance of this study of case which was made with these students inserted at the regular learning system through of Youth and Adult Education (EJA) modality. So, the main point is the considering the Phonovision Articulatory Method principles to the development of skills of phonological, phonemic and phonoaudio articulatory, at the literacy process of students with difficulty in codification (writing) and decodification (reading) of LM.

The research guided its investigation based on the following hypothesis: 1) the difficulties in learning of reading and writing informed by the students might be related with literacy method which they are exposed at school, featuring a methodological issue; 2) through the application of language principles of Phone Audio Articulatory Method, the PNEE's students may develop a phonemic (Phonemic conscience regards specifically the awareness of language phonemes) conscience, which might enable them to decode and, consequently, learn to read.

The absence of researches designed to these specific public, students enrolled in EJA justifies the relevance of the publication of this study of case. The pedagogic application of Phono Audio Articulatory Method by the means of MFVA materials, of Jardini $(2010 ; 2011)$ based on articulemes might make the process of reading easy and writing to students of inclusion with difficulty of domain the literacy principles (the alphabetic principle and the alphabetic letters (graphemes) don't represent sounds, and they do represent phonemes; the alphabetic principle is the first step to the reading learning, and it consists the better factor that predicts the reading development). The said Method applies concreted didactic resources (articulemes games, mirrors, microphones, etc.). These pedagogic instruments might consist in important tools to literacy of students of inclusion with CID 10 F10 and CID 10 F80. In both of cited trouble the chronological age of the person won't go along their cognitive developed age (Piaget, 1983), so even in adult age, the mental age it'll be permanently 09 to 12 , as well at the "operative concrete" stage (to (Piaget, 1983), in this phase, the child develops time notion, space, speed, order, concurrence, becoming capable of link different aspects and absorbs reality data. It doesn't limit to immediate representation, but still depends of concrete world to connect to abstraction).

In this context, we realize the permanency of "operative concrete" stage; the didactic resources must care primarily for the concreteness, and in this way, the articulemes might consist in some impulse to the developing process of the abilities of phonological conscience, phonemic and Phonovision Articulatory.

\section{Literature Revision}

The Phono Audio Articulatory Method (as known as "Little Mouth Method") is a literacy method, predicated in Articulatory Phonology (FAR). This sensorial literacy method of LM to Brazilian Portuguese has phono vision articulatory (The form of spell the word "phonetic-visual-articulatory" is own Jardini (2010) and in the form of spell "fonovísuoarticulatório". The first form is used when the author highlights the three factors that underlie the Fonovísuoarticulatório method. Since the term "fonovísuoarticulatório" is used to refer to the method itself) multi-sensorial base that provides, according to Jardini (2010), a better and fast school performance, as far the student is simultaneously submitted to several neuro-sensorial inputs.

To the author, these factors make easy the reading and writing learning, because there are bigger brain areas receiving these stimuli. The articulemes, ahead in the process, provide the acquiring of writing and reading. Yet, according to Jardini (2010), it is important to recognize:

$[\ldots]$ though the great gains and contributions to literacy, such in children with or without special need, the phonemic line is still too abstract, demanding a high level of attention and listening perception, because that, sometimes, it doesn't contemplate the whole of the students (p. 157).

The author suggests that this methodology needs of practical application, which it can't happen due the big number of students in the classroom. In this case, this study, the participation of few students in this research has helped in the method application. Another factor, according to the author, which affects the applicability of literacy methodology based on the phonemic is the characteristic noise of school ambient. At Jardini's (2010) con- 
ception, not even all the literacy teachers are ready to apply the phonemic exercises (such of articulation as well the orofacial reading), which demand, to its excellence, a reflection about the phonemes. This way, Jardini (2010: p. 157) adds:

[...] the lack of preparation of most of teachers in use their voices in classroom and, here, to produce phonemes, might result in phonological mistakes, overcharge and overacting of phonation, bringing to them negative consequences to vocal chords, such as dysphonia and other more critical alterations. As well is considerable the percentage of teachers whose do not know the real phonemes, twisting them, making mistakes and consequently, bringing it more detriments than benefits, by a dubious teaching, unsure and distant from the training and theoretical prepared $[\ldots]$.

So, the need of decode to come to phoneme level and, not only the syllable, that's why Jardini developed the Phono Audio Articulatory Method, with base in the Phonological Articulatory principles, which value the phonetic-phonological unity, that is, the articulatory gesture that allows the literacy student reach the necessary stimulus to be able of distinguish properly each one of the phonetic category (example, distinguish: ba and pa), as Figure 1 shows:

In this sense, Macedo (1998: p. 256) confirms that: "[...] the functional specialization of brain areas emerges much more probably because some of these areas are close to the sensorial input local of listening and seeing". So, the logic of Phonovision Articulatory Method is linked to synesthesia, that is, the sensations that provide the senses to teaching of mother language (in this case, the Portuguese language which is speaking in Brazil).

This study considers the Phonovision Articulatory principles as possibilities to development of the abilities of phonological conscience, phonemic and phonovision articulatory. This Method has an extensive script built by Jardini (2010: pp. 194-197). The MFVA, in a general way, starts with a work of student awareness about the importance and the function of literacy as goal to be experienced. The entire base of literacy by articulemes of MFVA its based at the work in multi-sensorial training which are used mirrors, microphones, recorders, earphones, pedagogic games and literacy student hands. The listening training is intense in a way which the

A

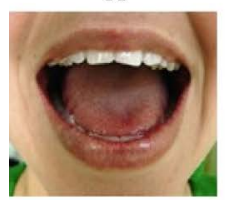

$\mathrm{P}$

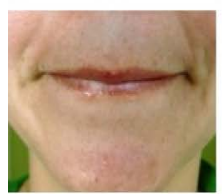

F

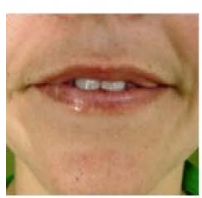

$\mathbf{J}$

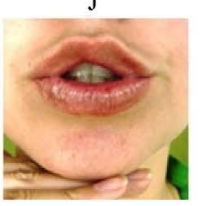

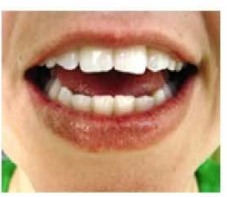

V

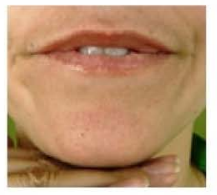

D

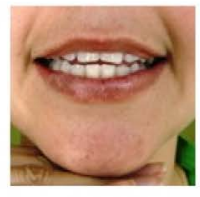

S

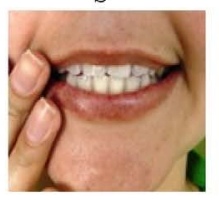

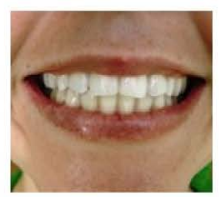

$\mathrm{T}$

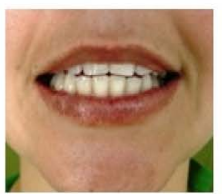

C - QU

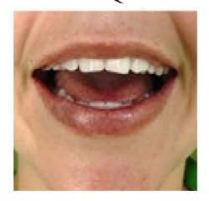

$\mathrm{X}-\mathrm{CH}$

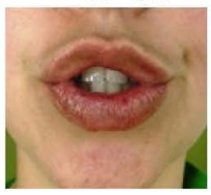

$\mathrm{O}$

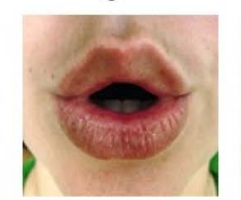

M

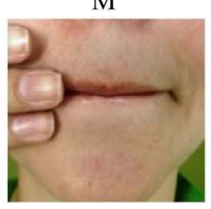

$R$ - RR

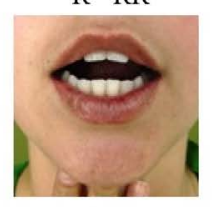

Z

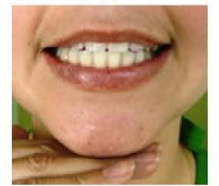

$\mathrm{U}$

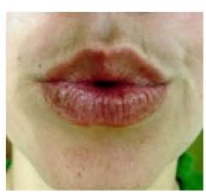

B

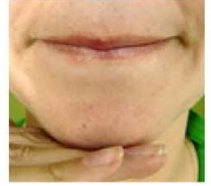

ARA

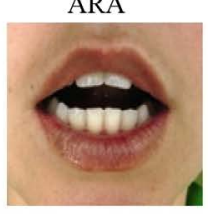

LH

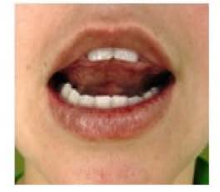

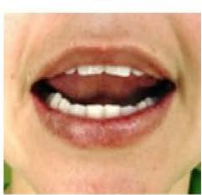

$\mathrm{N}$

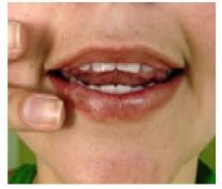

G - GU

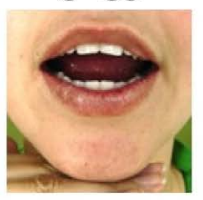

$\mathrm{NH}$

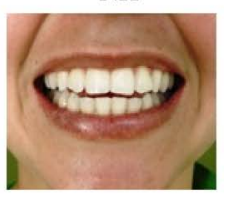

Exemple of Phono Audio Articulatory Method

Figure 1. Phono Audio Articulatory Method. 
student can make the phonographemics and graphonemics relations, after had developed their abilities of phonological awareness, phonemic and phono visio articulatory. The difficult grade of MFVA activities follow a growing level, so firstly are teaching the vowels followed by consonants and the syllabic family, everything by the means of articulemes.

According to Jardini (2010), the student, at the first moment, may think that the articulemes are overacted comparing the normal way of speaking, however, this overact in the way to articulate the phonemes is reduced so the process of decode and the codification are automatized by the student in literacy. By the Jardini's study (2010: p. 163), he assures that, after develop phono visio articulatory awareness, the students in literacy of his research express that the word "appear writing in their minds", and so they can write surely.

The "Little Mouth Method" recommends that the work with articulemes starts with vowels and, soon, with a predetermined sequence of consonants. Usually, the consonants are presented according their level of graphicphonemic transparency. This way, the literacy teacher might foresee which are of the phonemes by its similar articulation may cause confusion to the student (example: d-t; f-v; j-x-ch; s-ss-z).

The focus of this research is the verification on development of writing and reading in the (EJA), with emphasis in deal with the inclusion on that teaching modality. For such verification it was use as didactic resource the Phono Visio Artuculatory Method (MFVA) with intent to provide and make easier the development of conscience phonological abilities "sounds" (the term "sound", in this study, it'll be treated as that generic element which identify different sounds, example: cannon sound, honk, alarm clock, etc.), "phonemic" (according Dubois (2014: p. 262) this term "is used equally as synonymous for phonematic to designate the part of phonology which study exclusively the phonemes and different traces"), "phonemes" (the term "Phoneme", according Dubois (2014: p. 260) refers "the tiny unity dismissed of sense, liable of delimitation in speaking chain") and phono visio articulatory (articulemes-lalemas-visemas), at the initial literacy process.

To Jardini (2010: p. 158) articuleme is "the real mouth which make the sound", that is, the phones of the tongue. The term Phone, according Dubois (2014: p. 260) refers "the voice modulation due of phonic unities to be made by the excitation of different resonators. Called, sometimes, Phono the sounds of language, that is, each one of the real performances from a phonemes, variables as its phonic context.

The lalemas are bound to orofacial reading that, according to Capovilla et al. (2005: p. 980) is the "ability of understanding the speaking by the means of visemas-the visible correspondents of phonemes and lalemas". The visemas represent the visual patterns of the articulatory motion that might be observed in the face during the speaking (might be considered emotional expressions, as: joy, surprise, sadness, etc.). In some languages, certain phonemes can have the same visema, as example: $/ \mathrm{p}, / \mathrm{b} /, / \mathrm{m} /$. At deaf communities and signal languages, the visemas are considered too.

For this study, students with special needs were submit to the activities proposed according to the book Livro do Aluno: Alfabetização com as Boquinhas (Book Student: Alphabetization with tiny mouth), of Jardini (2011). Though this book is developed to literacy of children in initial process of Mother Language (LM), this study was applied in literacy of People with Special Educational Needs (PNEEs) at EJA.

\section{Method}

The delimitation of the research is organizing as from: literature revision, field research and reporting experience. The used instruments to the verification and to data collect were: semi-structured interviews, tests and pedagogic activities from the book Livro do Aluno: Alfabetização com as Boquinhas, Jardini (2011).

The sample selection was made through the choose of a public school which offered the teaching EJA modality and had students diagnosed with special needs; school records analysis from the persons indicated by the school, that is, the Performance Opinion (the Performance Opinion is related to ACI of inclusion student. At ACI the contents are drawn and minimal goals for the inclusion student may reach (according its limitations and possibilities). At the Performance Opinion is described as the contents and stated objectives at the ACI of the student were reached (in a determined timeline). To the students of inclusion, no quantitative grade were use, but a writing report to be analyzed for all the teachers whose deal with the student, together with other pedagogic segments and specialized at school) of the teacher about the performance of each student who participate of the survey, considering the possible difficulties of learning writing and reading, as well to make the Individual Curricular Adaptation (Adaptação Curricular Individualizada ACI-which consists in a curriculum to the students with medical report (that is, CID). Through the ACI, the contents might be adapted to the necessities and possi- 
bilities of each one of the inclusion students of the student with medical report ( $\mathrm{CID}^{1} 10 \mathrm{~F}^{2} 0^{2}$ e CID $\left.10 \mathrm{~F} 80^{3}\right)$. After the sample selection, the verification occurred by tests with grafeme, phonemic conscience level of the select persons, the MFVA application by tests with pseudo-words and, finally, the analysis of the obtained results from the testing made at the selected persons.

To selection of the school, a survey was made in Department of Education looking for information that revealed the literacy class with a bigger index of EJA students reprobated. To the elected school to intervention, was analyzed the Performance Opinion of each student in the class. By the means of this analysis were found three students with difficult of acquiring reading and writing. Each one of these students was enrolled at the school, at least, more than two years, that is, the most of them was repeating the school level by the second or third time, yet that, by the EJA system, each semester is equivalent to one stage (the curricular workload is organized by semesters with 400 hours distributed on 100 school days, according Parecer $n^{\circ} 750 / 2005$ of ConselhoEstadual de Educação do Rio Grande do Sul (Education State Council of Rio Grande do Sul-Brazil)).

The selected persons to participate on research: two carriers of light mental deficiency (CID 10 F70) and; one with phonological trouble due language delay, all of them with difficulties in acquiring writing and reading. From this selection, these persons followed an activities chronogram that was applied in the regular school time at the school which participant were enrolled.

During 60 school days (equivalent at five weekly meetings of four hours each, accounting two hundred and forty hours) the participants used Livro do Aluno: Alfabetização com as Boquinhas, Jardini (2011). Still accounted, as part of the research, eight hours related to scheduling, consenting terms, contacts to Education State Council and school management; eight hours to analysis of performance opinions, Individual curricular adaptations and medical reports of the students; and one hour referring to application of semi-structural interview together at class teacher, to identify the pedagogic aspects related to literacy process.

\section{Phonemic Conscience Test}

The objective of the test was analysis the phonemic awareness level of the literacy student before starts the work with Livro doAluno: Alfabetização com as Boquinhas, Jardini (2011).

\subsection{Phonemic Awareness Test (Table 1)}

Guidelines:

Researcher-I'm gonna articulate the sound of some letters. After hearing, follow the numbers in growing order, marking the chart bellow. After I articulate the letter, I ask to you that mark the sound that I articulated.

The phonemic awareness conscience is researcher scheme, to this study, and it's in concomitance with the levels and criteria of evaluation of Individuals Curricular Adaptations, of the participating students. During the test of phonemic awareness, the researcher articulated each grapheme ( 25 alphabetic letters) and asked the name of the grapheme and correspondent phoneme to the students. The right answers were charted by the researcher, as we'll see in the data analysis.

\subsection{Applied Activities from the Book Livro do Aluno: Alfabetização Com as Boquinhas}

This research prioritized the application of the steps of Phono Visio Articulatory Method in inclusion students from EJA. Therefore, each student received the book Livro do Aluno: Alfabetização com as Boquinhas, Jardini (2011). During the survey, as well, there were used of articulemes games suggested at the MFVA, that may help

Table 1. Note chart.
\begin{tabular}{cccccccccccccccc}
\hline 1 & 2 & 3 & 4 & 5 & 6 & 7 & 8 & 9 & 10 & 11 & 12 & 13 & 14 & 15 & 16 \\
17 & 18 & 19 & 20 & 21 & 22 & 23 & 24 & 25 & 26 & 27 & 28 & 29 & 30 & 31 & 32 \\
\hline
\end{tabular}

Researcher Observation, hits recorded.

\footnotetext{
${ }^{1}$ International Disease Classification (CID) is a code that identifies the diseases, by a publishing magazine by World Health Organization (OMS).

${ }^{2}$ International Disease Code for Light Mental Retardation.

${ }^{3}$ International Disease Code for Carriers of Language Delay.
} 
at the developing of the abilities of phonological conscience, phonemic and phono visio articulatory. During 60 school days the experiment with participating students the vowels were worked-a/e/i/o/u-, as well the consonants $/ 1 /$ and $/ \mathrm{p} /$. The activities made during the research were writing at the Livro do Aluno: Alfabetização com as Boquinhas, that each one of the students received freely, at the final of this survey.

\subsection{Pseudo-Words Test (Table 2)}

The test with pseudo-words (are words that have no sense, but they serve to evaluate if the student can identify the phoneme).was made at the end of the study to identify the phonemic conscience of the students who participated of the research, after the work with O Livro do Aluno: Alfabetização com as Boquinhas, Jardini (2011). The test was adapted according with grapheme and phoneme worked in the 60 school days (in case, /a/, /ã/, /e/, /é/, /i/, /o/, /ó/, /u/ and the consonants /l/,/p/).

Next, obtained results in the phonemic awareness test, previous the work with the book O Livro doAluno: Alfabetização com as Boquinhas, Jardini (2010), as well the results of the pseudo-words test made at the ending of the study.

\section{Analysis and Discussion of Data}

\subsection{Results of the Phonemic Awareness Tests}

The awareness phonemic test applied previously to the work with the book O Livro doAluno: Alfabetização com as Boquinhas. Each alphabetic grapheme was articulated and each word and phoneme correctly answered by the participating student was registered, as Table 3 shows below.

As to say the name of the grapheme, all of the students obtained five hits each. According to Jardini (2011: p. 195) this can happen due two facts:

Association of letter to the sound it produces (phoneme) and its identification among other five vowels. There might be coincidence between the letter's name and its sound, that's why the easy in acquiring and closing or fusion among the three inputs neuro-receptive, grapheme/phoneme/articuleme, from the five vowels.

The difficulty of students research in understand that the names of the grapheme do not correspond to its phoneme seems to reveal that the development of phoneme awareness still had not been working before.

\subsection{Phono Visio Articulatory Method: The Worked Activities during the Research}

The activities made together the students, during the research, they're written in the book Livro do Aluno: Alfabetização com as Boquinhas. The exercises of Portuguese language articuleme, proposed by the Phono Visio

Table 2. Note chart pseudo-words test. Researcher: read the pseudo-word bellow.

$\begin{array}{rlrrrr}\text { 1) APOE } & \text { 2) PELIO } & \text { 3) LUPEA } & \text { 4) PUAL } & \text { 5) LILEO } & \text { 6) OLPA } \\ \text { 7) PALUI } & \text { 8) LUIPO } & \text { 9) PILAL } & \text { 10) POPEA } & \text { 11) PLAI } & \text { 12) LIPA } \\ \text { 13) LAILO } & \text { 14) LOPO } & \text { 15) POLA } & \text { 16) PIPLO } & \text { 17) LOPIA } & \text { 18) PIAL }\end{array}$

Elaborated test by the researcher at the occasion, to the informants characteristic and the grapheme and phoneme worked in the research period $(/ \mathrm{a} /$, /ã/, /e/, /é/, /i/, /o/, /ó/, /u/) and consonants (/l/, /p/).

Table 3. Chart 1-results of phonemic awareness.

\begin{tabular}{|cccc}
\hline Informant Research & $\begin{array}{c}\text { Letters alphabet articulated } \\
\text { by the researcher }\end{array}$ & $\begin{array}{c}\text { Total Hit (s) to name } \\
\text { grapheme by the student }\end{array}$ & $\begin{array}{c}\text { Total Hit (s) for phoneme by } \\
\text { the student }\end{array}$ \\
\hline Informant A & 25 & 23 & 5 \\
Informant B & 25 & 25 & 5 \\
Informant C & 25 & 18 & 5 \\
Informant D & 25 & 18 & 5 \\
\hline
\end{tabular}

Test elaborated by the researcher to this survey. 
Articulatory Method, worked on the research, subsidized by the frequent use of mirrors, microphones, games, CDs, banners and articuleme posters. The applied games during the study are integrant part of ColeçãoJogos de Boquinhas (Collection tiny mouth Games) of Jardini. We can point that the activities from the book Livro do Aluno were made following the rules of each Individual's Curricular Adaptation (ACI) of the participating students.

The grapheme and phoneme worked during the research time, before mentioned, were the vowels $/ \mathrm{a} /, / \mathrm{a} /$, /e/, /é/, /i/, /o/, /ó/, /u/ and the consonants /l/, /p/ The activities made at the working process had as specific goals the central theme of this research, as: the development of the abilities of phonological awareness, phonemic and phono visio articulatory.

\subsection{Pseudo-Words Tests Results}

The tests with pseudo-words were applied in this research to evaluate the phonemic awareness level reached by the students, after the work with phono visio articulatory method and to rate the writing hypothesis according to Ferreiro \& Teberosky (1984).

According to Perfett's studies (1985) and Rack, Snowling, \& Olson (1992) there are an indicative of additional evidence that the reading of unknown words or of pseudo-words reveal itself as the most powerful factor to discern the general capacity of reading. That is, according to O Poder Legislativo e a Alfabetização Infantil; osnovoscaminhos (The Legislature and the Children's Alphabetization; new paths) report, "pseudo-words consists as an important pointer of proficiency to decode, once that eliminate the guessing possibility which might occur in the word identification" (Capovilla \& Capovilla, 2004: p. 60). The application of these tests intents to set aside the reading possibilities by guessing from the literacy's student and verify if the abilities of phonemic awareness and Phono Visio Articulatory were properly developed.

The test consists in 18 pseudo-words to be pronounced high voiced by the literacy's student. Following, as Table 4 shows, the reached results by the participants at the final tests with pseudo-words.

After three months of working with Phono Visio Articulatory method, all of the students, in this test, reached a measure between 12 and 15 hits (2/3 from the 18 proposed words in the test). The reached results might confirm that, through the Phono Visio Articulatory Method principles, the students with light mental deficit and those with language delay might develop a proper level of phoneme awareness, which allow them to reach the alphabetic hypothesis accordin to Ferreiro and Teberosky (1984).

\section{Discussion of the Results}

At the first stage of the research, by means the analysis of Performance Opinion of each one of the students, some difficulties were diagnosed in relation to code and decode abilities. This way, based too in Individual's Curricular Adaptation the pedagogical resources were organized and the tests to make the research together to the students.

By the phonemic awareness was possible to identify the phonemic awareness level of the students, before of the work with Phono Visio Articulatory Method. In this test, from 25 grapheme phono-articulated by the researcher, the students reached 18 to 25 hits to the name of the grapheme; yet in relation to the value of sound of the grapheme, all of them had 5 hits. That occurred due the fact that the five hits obtained by the students refer itself exactly to the five vowels (/a/, /e/, /i/,/o/, /u/). According to Jardini (2010: p. 195), the identification of the five vowels refer itself "to coincidence between the name of the letter and its sound, that's why the easy in the acquiring”. And it point that the phoneme /á/, /ã/, /é/, /ó/, /ô/ were questioned in this test as well.

Table 4. Chart 2-test of pseudo-words results.

\begin{tabular}{ccc}
\hline Informant Research & Total of Pseudo-word & Total hits reached \\
\hline Informant A & 18 & 13 \\
Informant B & 18 & 15 \\
Informant C & 18 & 12 \\
Informant D & 18 & 12 \\
\hline
\end{tabular}


By the means of application of MFVA's pedagogical principles through the use of the book Livro do Aluno: Alfabetização com as Boquinhas, with inclusion students was verified the facilitation to development of phonological awareness abilities, phonemic and Phono Visio Articulatory, considering that after the MFVA application in all of the students, in a total of 18 pseudo-words proposed by the test, they hit a measure between 12 to 15 hits. The number of the hits by each one of the students suggests that through the Phono Visio Articulatory principles is possible to develop an appropriated level of phonemic awareness with PNEEs students.

From the obtained results with this under study group we can say that the second hypothesis of this research was confirmed, in a way that the work with MFVA seems to develop abilities of phonological awareness, phonemic and Phono Visio Articulatory, in view of the accession of the informants by the vision-sensorial activities (by mirrors, microphones, games, etc.). As to the first hypothesis, confirm itself as well, once that there are few the developed researches in this investigation area and believe that the teaching-learning methods with PNEEs students must be re-evaluated, as well the teachers in this modality need constant capacitation that able them to develop and apply new methods and resources to the development of reading and writing to adult students of inclusion enrolled at the EJA.

\section{Final Considerations}

At first, it was verified by test of phonemic awareness that the students of the research that they identified the grapheme, however, during the field research were noticed through oral dictation; that the participants were not skilled in the reading and writing process. The three participating students were at syllabic hypothesis II according to Ferreiro and Teberosky (1984).

However, after two months of working with the Phono Visio Articulatory, as verified, by a specific test with pseudo-words, this method seems to develop a suitable level of phonemic awareness and of decode in literacy's student of inclusion, since it is noticed that the students hit more than half in a total of the proposed words to the decode, in the test with pseudo-words. There was an evolution to the syllabic-alphabetic hypothesis according to Ferreiro and Teberosky (1984).

Based on the obtained results with this study of case, we realize that the book Livro do Aluno: Alfabetização com as Boquinhas, even was developed to children's use, it could be applied with literacy's students that have light mental deficit and for those whose language delayed, in reason of the mental age of these persons that could vary from 6 to 12. However, it is suggested that wider experimental studies might be made together to persons with these characteristics to analyze the possibility of using the book Livro do Aluno: Alfabbetização com Boquinhas, as well, the games of the MFVA's collection, as well as the development of new didactical methodologies that might be adaptable to the socio-cultural reality of the teaching institutions that these persons are included.

\section{References}

Capovilla, A. G. S., \& Capovilla, F. C. (2004). Literacy: Phonic Method (3rd ed.). São Paulo: Memnon, Fapesp, CNPq.

Capovilla, A. G. S., Capovilla, F. C., Viggiano, K., Capovilla, A. G. S., Bidá, M., Neves, M., \& Mauricio, A. (2005). How to Evaluate the Development of Reading Comprehension of Sentences in Deaf People of Basic School to High School, and Analyze Syntactic Processing to Extract Meaning: Original Version Validated and Standardized the Sentences Reading Competence Test. In F. C. Capovilla, \& W. D. Raphael (Eds.), Encyclopedia of Language Brazilian Signs: World's Deaf in Pounds (Vol. 3, pp.) São Paulo: Edusp.

Dubois, J. et al. (2014) Language Dictionary. São Paulo: Cultrix.

Ferreiro, E., \& Teberosky, A. (1984). Psychogenesis of Written Language. São Paulo: Artes Médicas.

Jardini, R. S. R. (2010). Alphabetization and Rehabilitation by the Method of Mouths: Theoretical Foundation. Bauru: Boquinhas Aprendizagem e Assessoria.

Jardini, R. S. R., \& Gomes, P. S. (2011). Book Student: Literacy with “Boquinhas”: Method-Visual-Articulatory. São Paulo: Boquinhas Aprendizagem e Assessoria, Bauru.

Macedo, L. (1998). Clinical Method and School Evaluation. Constructivist Trials. São Paulo: Casa do Psicólogo.

Meleti, S. M. F. (2014). Educational Indicators on Special Education in Brazil and in Paraná.Education \& Reality. Vol. 39, No. 3, Porto Alegre July/September 2014, Disponível em:

http://www.scielo.br/scielo.php?pid=S2175-62362014000300009\&script=sci_arttext

Perfett, C. A. (1985). Reading Ability. New York: Oxford University Press. 
M. B. Brizola

Piaget, J. (1983) The Genetic Epistemology. Sao Paulo: Abril Cultural.

Rack, J. P., Snowling, M. J., \& Olson, R. K. (1992). The Non-Word Reading Deficit in Developmental Dyslexia: A Review. Reading Research Quarterly, 27, 28-53. http://dx.doi.org/10.2307/747832 